\title{
DAMPAK LALU LINTAS TERHADAP PEMBANGUNAN FAKULTAS KEDOKTERAN GIGI UNIVERSITAS LAMBUNG MANGKURAT
}

\author{
Mulyadi $^{1}$ \\ ${ }^{1}$ Program Studi Teknik Sipil, Fakultas Teknik, \\ Universitas Islam Kalimantan Muhammad Arsyad Al Banjari Banjarmasin \\ E-mail: mulyadi.uniska37@gmail.com HP.+628115004627
}

\begin{abstract}
ABSTRAK
Perubahan struktur ruang kota akan berpengaruh kepada pola pergerakan yang pada akhirnya akan membebani jaringan jalan yang ada di suatu wilayah. Dengan kata lain, setiap rencana pengembangan kegiatan dan/atau usaha di suatu kawasan akan memberikan dampak terhadap wilayah di sekitarnya, termasuk dampaknya terhadap lalu lintas jalan. Penelitian dampak lalu lintas terhadap Pembangunan Fakultas Kedokteran Gigi secara administratif di kecamatan Banjarmasin utara, Kota Banjarmasin, Provinsi Kalimantan Selatan, tepatnya di jalan Hasan Basri yang merupakan Jalan Nasional (Kode Ruas 001.11.K). Tujuan menganalisis kinerja jaringan jalan pada kawasan rencana pembangunan baik pada kondisi eksisting, saat pekerjaan, maupun pasca pembangunan. Hasil dari Kondisi eksisting Jl. Hasan Basri (BPJS - Bundaran) sudah memperlihatkan nilai DS dibawah nilai batas (> 0,75). Kondisi ini tanpa maupun dengan adanya pembangunan sudah perlu ada penanganan. Dengan dilakukan penanganan manajemen dan rekayasa lalu lintas dengan melakukan manajemen simpang bersinyal nilai DS menjadi kurang dari 0,75. Untuk tahun selanjutnya perlu melakukan review dan evaluasi terhadap kinerja jaringan jalan agar tetap baik
\end{abstract}

Kata Kunci : Penanganan Dampak Lalu Lintas.

\begin{abstract}
Changes in the structure of urban space will affect the pattern of movement which in turn will burden the existing road network in an area. In other words, every activity and/or business development plan in an area will have an impact on the surrounding area, including its impact on road traffic. Research on the impact of traffic on the development of the Faculty of Dentistry is administratively located in the northern district of Banjarmasin, Banjarmasin City, South Kalimantan Province, precisely on Hasan Basri Street which is a National Road (Section Code 001.11.K). The aim is to analyze the performance of the road network in the planned development area, both in the existing condition, during work, and after construction. Result of the existing condition Jl. Hasan Basri (BPJS - Bundaran) has shown the DS value below the limit value (>0.75). This condition, without or with development, needs to be handled. By handling traffic management and engineering by managing signalized intersections, the DS value becomes less than 0.75 . For the next year, it is necessary to review and evaluate the performance of the road network so that it remains good
\end{abstract}

Keywords : Traffic Impact Handling. 


\section{PENDAHULUAN}

\section{Latar Belakang}

Sebagaimana diketahui bersama bahwa keberadaan jalan menjadi kunci dari perkembangan suatu wilayah atau kota. Jaringan jalan akan terbentuk yang salah satu fungsinya untuk menghubungkan antara kota satu dengan kota lain yang terdekat secara administrasi dan antar zona pada kota itu tersebut. Fungsi jalan utama antara lain bertujuan untuk memperlancar pergerakan arus manusia dan barang sehingga dapat mendukung aktivitas ekonomi secara nasional. Dengan demikian, maka keberadaan jalan seharusnya tidak terpengaruhi oleh hambatanhambatan yang terjadi. Oleh karenanya perlu dilakukan penataan dan pengawasan serta pengendalian terhadap perkembangan suatu wilayah dalam suatu kota dalam rangka mengantisipasi perkembangan kegiatan dan aktivitas masyarakat. Seiring dengan berjalannya waktu, perkembangan kota, dan tata guna lahan selalu berkembang dan berubah mengikuti kebutuhan dan kebijakan pembuat keputusan, baik dilingkungan pemerintahan daerah maupun Pemerintah Pusat. Salah satu perkembangan dari tata guna lahan di perkotaan adalah adanya perubahan peruntukan kawasan yang berubah menjadi pusat-pusat kegiatan. Baik pusat kegiatan yang bersifat jasa komersial maupun pusat kegiatan yang bersifat pelayanan kepada masyarakat. Perubahan struktur ruang kota akan berpengaruh kepada pola pergerakan yang pada akhirnya akan membebani jaringan jalan yang ada di suatu wilayah. Dampak lalu lintas jalan tersebut perlu diantisipasi dan ditangani secara tepat sesuai dengan lokasi, jenis, dan skala dampak yang akan ditimbulkannya. Rencana Pembangunan Fakultas Kedokteran Gigi oleh Universitas Lambung Mangkurat berlokasi di Kawasan universitas di Jl. Hasan Basri, Kecamatan Banjarmasin Utara Kota Banjarmasin Provinsi Kalimantan Selatan. Kondisi akses jalan ke/dari lokasi penelitian umumnya sangat baik dan melalui Jalan Nasional. Fakultas Kedokteran Gigi rencana dikembangkan di atas tanah seluas 7,2 Ha dengan luas lantai bangunan Fakultas Kedokteran Gigi direncanakan dengan luas total $\pm 1.584 \mathrm{~m}^{2}$ untuk 5 lantai. Jumlah mahasiswa yang akan menggunakan fakultas tersebut sebanyak 794 mahasiswa, untuk mengetahui dampak lalu lintas yang dtimbulkan, maka perlu dilakukan penelitian terhadap kinerja jaringan jalan.

\section{Tujuan Penelitian}

Sedangkan tujuan dari penelitian ini adalah:

1. Menganalisis kinerja jaringan jalan pada kawasan rencana pembangunan baik pada kondisi eksisting, saat pekerjaan, maupun pasca pembangunan.

2. Mencari solusi terbaik dalam penanggulangan masalah transportasi perkotaan, terutama untuk mengatasi permasalahan dibidang lalu lintas akibat dari dampak pembangunan yang direncanakan.

\section{Definisi:}

\section{Analisis dampak lalu lintas jalan (andalalin)}

Suatu studi khusus yang dilakukan untuk menilai dampak lalu lintas jalan.

\section{Arus lalu lintas}

Jumlah kendaraan bermotor yang melewati suatu titik pada jalan per satuan waktu (Manual Kapasitas Jalan Indonesia, 1997).

\section{Bangkitan perjalanan}


Jumlah perjalanan orang dan / atau kendaraan yang keluar-masuk suatu kawasan,rata-rata per hari atau selama jam puncak, yang dibangkitkan oleh kegiatan dan / atau usaha yang ada didalam kawasan tersebut.

4. Dampak lalulintas jalan

Pengaruh yang dapat mengakibatkan perubahan tingkat pelayanan pada ruas dan / atau persimpangan jalan yang diakibatkan oleh lalu lintas jalan yang dibangkitkan suatu kegiatandan / atau usaha pada suatu kawasan tertentu.

5. Derajat kejenuhan (degree of saturation)

Rasio arus lalu lintas terhadap kapasitas pada ruas jalan atau persimpangan jalan tertentu (Manual Kapasitas Jalan Indonesia, 1997).

6. Distribusi perjalanan

Distribusi bangkitan perjalanan menurut lokasi atau zona asal dan tujuan.

7. Jalan

Prasarana transportasi darat yang meliputi segala bagian jalan, termasuk bangunan pelengkap dan perlengkapannya yang diperuntukkan bagi lalu lintas, yang berada pada permukaan tanah, di atas permukaan tanah, di bawah permukaan tanah dan / atau air, serta di atas permukaan air, kecuali jalan kereta api, jalan lori, dan jalan kabel (Undang-Undang No. 38 Tahun 2004, Peraturan Pemerintah No. 34 Tahun 2006).

8. Jam puncak

Jam pada saat arus lalu lintas di dalam jaringan jalan pada kawasan yang ditinjau berada pada kondisi maksimum.

9. Jaringan jalan

Sekumpulan ruas jalan dan persimpangan jalan yang merupakan satu kesatuan yang terjalindalam hubungan hierarki (Peraturan Menteri Perhubungan No. KM 14 Tahun 2006 dan No.PM 96 Tahun 2015).

10. Kapasitas

Jumlah maksimum kendaraan yang dapat melewati suatu ruas jalan atau persimpangan jalantertentu selama periode waktu tertentu dalam kondisi jalan dan lalu lintas yang ideal.

\section{Kawasan}

Wilayah yang batasnya ditentukan berdasarkan lingkup pengamatan fungsi tertentu.

\section{Kawasan perkotaan}

Wilayah yang mempunyai kegiatan utama bukan pertanian dengan susunan fungsi sebagai tempat permukiman perkotaan, pemusatan, dan distribusi pelayanan jasa pemerintahan, pelayanan sosial, dan kegiatan ekonomi (Undang-Undang No. 26 Tahun 2007).

\section{Kecepatan lalu lintas}

Kemampuan untuk menempuh jarak tertentu dalam satuan waktu, dinyatakan dalam kilometer per jam (Manual Kapasitas Jalan Indonesia, 1997).

\section{Pembebanan lalu lintas}

Pembebanan lalu lintas kendaraan hasil distribusi perjalanan ke dalam jaringan jalan dalamsatuan waktu.

\section{Pengembangan kawasan}

Suatu kegiatan yang menyebabkan adanya perubahan skala dan/atau jenis kegiatan dan/atauusaha di suatu kawasan.

16. Tingkat pelayanan 
Kemampuan ruas jalan dan/atau persimpangan jalan untuk menampung lalu lintas pada keadaan tertentu (Peraturan Menteri Perhubungan No. KM 14 Tahun.

\section{METODE PENELITIAN}

\section{Lokasi dan Waktu Penelitian}

Penelitian dampak lalu lintas terhadap Pembangunan Fakultas Kedokteran Gigi secara administratif di kecamatan Banjarmasin utara, Kota Banjarmasin, Provinsi Kalimantan Selatan, tepatnya di jalan Hasan Basri yang merupakan Jalan Nasional (Kode Ruas 001.11.K). Waktu penelitian dilaksanakan pada bulan November 2021.

\section{Langkah-Langkah Penelitian}

\section{Persiapan}

Pada tahap ini dilakukan identifikasi masalah \& kondisi lingkungan setempat untuk merumuskan metode pelaksanaan pekerjaan di lapangan.

2. Studi literatur
a. Pengumpulan dan tinjauan literatur/referensi dari kegiatan baik dari textbook maupun dari hasil studi terdahulu, jurnal/proceeding terutama yang berkaitan dengan andalalin.
b. Pengumpulan dan tinjauan terhadap Norma, Standar, Pedoman, dan Manual (NSPM) yang berkaitan dengan andalalin.
c. Pengumpulan dan tinjauan terhadap peraturan/regulasi terkait pekerjaan di atas yang baku seperti Peraturan Per Undang-undangan, Keputusan Presiden, Keputusan Menteri, Peraturan Daerah, dan SK Gubernur.

3. Koordinasi dan pengumpulan data

\section{a. Koordinasi}

Pada tahapan awal koordinasi dilakukan dengan pemberi kerja sebagai sumber informasi yang pertama. Koordinasi ini untuk mendapatkan masukan mengenai keterkaitan instansi lain bila diperlukan dalam pelaksanaan pekerjaan ini. Setelah melakukan koordinasi dengan pemberi kerja maka selanjutnya adalah tahap koordinasi dengan berbagai instansi terkait seperti yang diarahkan oleh pemberi kerja. Maksud dari koordinasi lanjutan adalah untuk mendapatkan berbagai masukan, pertimbangan, dan kerjasama dari berbagai pihak terkait

b. Pengumpulan Data

Pengumpulan data atau survei terbagi menjadi 2 (dua) bagian yaitu;

1) Survey instansional

2) Survey lapangan

Tahap pengumpulan data penting karena diharapkan perangkat (instrumen/format-format) pengumpulan data yang digunakan merupakan instrumen yang spesifik, terintegrasi di dalam kerangka kerja. Dengan kata lain, pengembangan instrumen tersebut layak untuk mendukung pelaksanaan input data dan evaluasi akhir hasil kegiatan penelitian dan berdampak pada sasaran penerima manfaat penelitian. Perhatian peneliti akan difokuskan pada metodologi pengumpulan data yang sudah pernah digunakan atau cocok diterapkan untuk penelitian yang mempunyai karakteristik sejenis. 
4. Identifikasi keberhasilan dan pemasalahan

Data primer yang terkumpul dikaji ulang dan ditelaah dalam menetapkan kebutuhan pengembangan transportasi perkotaan. Untuk menunjang aspirasi tersebut, diperlukan rangkaian kegiatan diskusi teknis, evaluatif, dan normatif.

5. Analisis data

Pada tahapan ini akan dilakukan analisis terhadap data dan informasi yang telah diperoleh secara kualitatif dan kuantitatif. Adapun metode yang dilakukan untuk menganalisis adalah dengan metode pendekatan empiris. Dalam analisis ini dilakukan terhadap kawasan studi yang telah ditentukan.

6. Penyusunan materi teknis

Penyusunan materi teknis andalalin berdasarkan tahapan yang telah dilakukan sebelumnya, maka akan disusun materi teknis keterpaduan perencanaan tersebut sebagai dasar perencanaan menyeluruh tentang andalalin. Sebagai gambaran, materi teknis yang akan dihasilkan adalah sebagai berikut :
a. Pendahuluan
b. Metodologi dan Pendekatan
c. Tinjauan Analisis
d. Penutup

\section{Kriteria kebutuhan penanganan dampak lalu lintas jalan}

Untuk setiap elemen dampak lalu lintas jalan yang diukur harus ditetapkan apakah menghasilkan masalah yang harus ditangani atau tidak. Pada Tabel 1. disampaikan kriteria berupa nilai batas dari indikator dampak lalu lintas jalan yang membutuhkan penanganan.

Tabel 1. Kriteria Dampak Lalu Lintas Jalan Yang Membutuhkan Penanganan

\begin{tabular}{|c|c|c|c|}
\hline Lokasi & $\begin{array}{c}\text { Elemen } \\
\text { dampak lalu } \\
\text { lintas jalan }\end{array}$ & $\begin{array}{l}\text { Indikator dampak lalu } \\
\text { lintas jalan }\end{array}$ & $\begin{array}{l}\text { Kriteria dampak lalu lintas jalan } \\
\text { yang membutuhkan penanganan }\end{array}$ \\
\hline & $\begin{array}{l}\text { Lalu lintas } \\
\text { kendaraan }\end{array}$ & $\begin{array}{l}\text { a) Derajat kejenuhan; } \\
\text { b) Kecepatan lalu } \\
\text { lintas diruas jalan } \\
\text { (kilometer per } \\
\text { jam). }\end{array}$ & $\begin{array}{l}\text { a) Derajat kejenuhan lebih dari atau } \\
\text { sama dengan 0,75; } \\
\text { b) Kecepatan di jalan arteri kurang } \\
\text { dari } 30 \text { kilometer per jam; } \\
\text { c) Kecepatan di jalan kolektor } \\
\text { kurang dari } 20 \text { kilometer per } \\
\text { jam. }\end{array}$ \\
\hline Ruas jalan & $\begin{array}{l}\text { Lalu lintas } \\
\text { pejalan kaki }\end{array}$ & Tingkat pelayanan & $\begin{array}{l}\text { a) Tingkat pelayanan kurang dari A } \\
\text { untuk kawasan perumahan; } \\
\text { b) Tingkat pelayanan kurang dari A } \\
\text { untuk wilayah di sekitar } \\
\text { kawasan komersial; } \\
\text { c) Tingkat pelayanan kurang dari B } \\
\text { untuk kawasan bisnis / } \\
\text { perkantoran; } \\
\text { d) Tingkat pelayanan kurang dari C } \\
\text { untuk kawasan lainnya. }\end{array}$ \\
\hline
\end{tabular}




\begin{tabular}{|c|c|c|c|c|}
\hline & $\begin{array}{l}\text { Lalu lintas } \\
\text { kendaraan }\end{array}$ & $\begin{array}{l}\text { a) Derajat kejenuhan; } \\
\text { b) Tundaan (detik per } \\
\text { smp). }\end{array}$ & a) & $\begin{array}{l}\text { Derajat kejenuhan lebih dari atau } \\
\text { sama dengan } 0,75 \text {; } \\
\text { Tundaan lebih dari } 30 \text { detik per } \\
\text { smp. }\end{array}$ \\
\hline $\begin{array}{l}\text { Persimpangan } \\
\text { jalan }\end{array}$ & $\begin{array}{l}\text { Lalu lintas } \\
\text { pejalan kaki }\end{array}$ & Tingkat pelayanan & $\begin{array}{l}\text { a) } \\
\text { b) } \\
\text { c) } \\
\text { d) }\end{array}$ & $\begin{array}{l}\text { Tingkat pelayanan kurang dari A } \\
\text { untuk kawasan perumahan; } \\
\text { Tingkat pelayanan kurang dari A } \\
\text { untuk wilayah di sekitar } \\
\text { kawasan komersial; } \\
\text { Tingkat pelayanan kurang dari B } \\
\text { untuk kawasan bisnis / } \\
\text { perkantoran; } \\
\text { Tingkat pelayanan kurang dari C } \\
\text { untuk kawasan lainnya. }\end{array}$ \\
\hline
\end{tabular}

Sumber: DEPARTEMEN PEKERJAAN UMUM (Pedoman analisis dampak lalulintas jalan akibat pengembangan kawasan diperkotaan)

\section{Analisis Kinerja Ruas Jalan dan Persimpang}

Standar baku yang dapat digunakan untuk mengukur kinerja lalu lintas adalah Manual Kapasitas Jalan Indonesia (MKJI) dan sofware KAJI 1997 yang di terbitkan oleh Direktorat Jenderal Bina Marga tahun 1997. Standar ini didesain sesuai dengan kondisi lalu lintas di Indonesia, sebagai berikut:

\section{Satuan Mobil Penumpang}

Ekivalen mobil penumpang untuk jalan perkotaan dikelompokkan dalam kondisi jalan perkotaan tak-terbagi dan jalan perkotaan terbagi /satu-arah seperti terlihat pada Tabel 2. dan Tabel 3.

Tabel 2. EMP untuk Jalan Perkotaan Tak-Terbagi

\begin{tabular}{|l|c|c|c|c|}
\hline \multirow{2}{*}{$\begin{array}{l}\text { Tipe jalan: } \\
\text { Jalan tak terbagi }\end{array}$} & \multirow{2}{*}{$\begin{array}{c}\text { Arus lalu-lintas } \\
\text { total dua arah } \\
\text { (kend/jam) }\end{array}$} & \multirow{2}{*}{ HV } & & \multicolumn{2}{|c|}{ Emp } \\
\cline { 4 - 5 } & & & \multicolumn{2}{|c|}{ MC } \\
\cline { 4 - 5 } & & & \multicolumn{2}{|c|}{ Lebar jalur lalu-lintas $\mathrm{W}_{\mathrm{C}}(\mathrm{m})$} \\
\hline Dua-lajur tak-terbagi & $0-1800$ & 1,3 & 0,5 & $>0,4$ \\
(2/2 UD) & $\geq 1800$ & 1,2 & 0,35 & 0,25 \\
\hline Empat-lajur tak-terbagi & $0-3700$ & 1,3 & \multicolumn{2}{|c|}{0,4} \\
(4/2 UD) & $\geq 3700$ & 1,2 & \multicolumn{2}{|c|}{0,25} \\
\hline
\end{tabular}

Sumber: MKJI'97

Tabel 3. EMP untuk Jalan Perkotaan Terbagi dan Satu-arah

\begin{tabular}{|l|c|c|c|}
\hline Tipe jalan: & Arus lalu-lintas per lajur & \multicolumn{2}{|c|}{ emp } \\
\cline { 3 - 4 } Jalan satu arah dan Jalan terbagi & (kend/jam) & HV & MC \\
\hline Dua-lajur satu-arah (2/1) dan & $0-1050$ & 1,3 & 0,4 \\
Empat-lajur terbagi (4/2D) & $\geq 1050$ & 1,2 & 0,25 \\
\hline Tiga-lajur satu-arah (3/1) dan & $0-1100$ & 1,3 & 0,4 \\
Enam-lajur terbagi (6/2D) & $\geq 1100$ & 1,2 & 0,25 \\
\hline
\end{tabular}

Sumber: MKJI'97 


\section{Ruas Jalan Perkotaan}

Untuk jalan tak terbagi, analisis dilakukan pada kedua arah lalu-lintas. Untuk jalan terbagi, analisis dilakukan terpisah pada masing-masing arah lalu-lintas, seolah-olah masing-masing arah merupakan jalan satu arah yang terpisah. Formula untuk menentukan kapasitas Jalan Perkotaan adalah sebagai berikut: $\mathrm{C}=\mathrm{C} 0 \times \mathrm{FCw} \times \mathrm{FCsP} \times \mathrm{FCsF} \times \mathrm{FCcs}$

Dimana:

$\mathrm{C} \quad=$ Kapasitas sesungguhnya ( $\mathrm{smp} / \mathrm{jam})$

$\mathrm{C}_{0} \quad=$ Kapasitas dasar (smp/jam)

$\mathrm{FCW}=$ Faktor penyesuaian akibat lebar jalur lalu lintas

FCsP $=$ Faktor penyesuaian akibat pemisahan arah

FCsF $=$ Faktor penyesuaian akibat hambatan samping

FCcs $=$ Faktor penyesuaian akibat ukuran kota

Kapasitas dasar $\left(\mathrm{C}_{0}\right)$ ditentukan berdasarkan tipe jalan seperti terlihat pada Tabel 4.

Tabel 4. Kapasitas Dasar $\left(\mathrm{C}_{0}\right)$ Jalan Perkotaan

\begin{tabular}{|l|c|l|}
\hline \multicolumn{1}{|c|}{ Tipe jalan } & Kapasitas dasar (smp/jam) & \multicolumn{1}{c|}{ Catatan } \\
\hline Empat-lajur terbagi atau & 1650 & Per lajur \\
Jalan satu-arah & & \\
Empat-lajur tak-terbagi & 1500 & Per lajur \\
Dua-lajur tak-terbagi & 2900 & Total dua arah \\
\hline
\end{tabular}

Sumber: MKJI'97

Faktor Penyesuaian untuk lebar jalur lalu-lintas ditentukan berdasarkan lebar jalur lalu-lintas efektif (W) seperti terlihat pada Tabel 5.

Tabel 5. Faktor Penyesuaian Lebar Lalu Lintas Efektif ( $\mathrm{W}_{\mathrm{C}}$ ) Jalan Perkotaan

\begin{tabular}{|l|c|c|}
\hline \multicolumn{1}{|c|}{ Tipe jalan } & Lebar jalur lalu-lintas efektif $(\mathrm{Wc})(\mathrm{m})$ & $\mathrm{FC}_{\mathrm{W}}$ \\
\hline Empat-lajur & Per lajur & \\
terbagi atau & 3,00 & 0,92 \\
Jalan satu-arah & 3,25 & 0,96 \\
& 3,50 & 1,00 \\
& 3,75 & 1,04 \\
& 4,00 & 1,08 \\
\hline Empat-lajur tak- & Per lajur & \\
terbagi & 3,00 & 0,91 \\
& 3,25 & 0,95 \\
& 3,50 & 1,00 \\
& 3,75 & 1,05 \\
\hline
\end{tabular}

Sumber: MKJI'97

Faktor penyesuaian kapasitas untuk jalan lebih dari empat lajur dapat ditentukan denganmenggunakan nilai per lajur yang diberikan untuk jalan empat-lajur dalam Tabel 5.

Faktor penyesuaian kapasitas untuk pemisahan arah ditentukan berdasarkan data masukan kondisi lalu-lintas seperti terlihat pada Tabel 6. 
Tabel 6. Faktor Penyesuaian Pemisah Arah untuk Jalan Dua-Lajur Dua-Arah (2/2) danEmpat-Lajur Dua-Arah (4/2) Tak Terbagi

\begin{tabular}{|l|l|c|c|c|c|c|}
\hline \multicolumn{2}{|c|}{ Pemisahan arah SP \%-\% } & $50-50$ & $55-45$ & $60-40$ & $65-35$ & $70-30$ \\
\hline \multirow{2}{*}{ FC SP } & Dua-lajur 2/2 & 1,00 & 0,97 & 0,94 & 0,91 & 0,88 \\
\cline { 2 - 7 } & Empat-lajur 4/2 & 1,00 & 0,985 & 0,97 & 0,955 & 0,94 \\
\hline
\end{tabular}

Sumber: MKJI'97

Faktor Penyesuaian Kapasitas Untuk Hambatan Samping $\left(\mathrm{Fc}_{\mathrm{sf}}\right)$ JalanPerkotaan 1. Jalan dengan bahu

Faktor penyesuaian kapasitas untuk hambatan samping ditentukan berdasarkan lebar bahuefektif Ws dan kelas hambatan samping (SFC) seperti terlihat pada Tabel 7.

Tabel 7. Faktor Penyesuaian Kapasitas Pengaruh Hambatan Samping dan Lebar Bahu(FCSF) pada Jalan Perkotaan dengan Bahu

\begin{tabular}{|c|c|c|c|c|c|}
\hline \multirow{3}{*}{ Tipe jalan } & \multirow{3}{*}{$\begin{array}{c}\text { Kelas } \\
\text { hambatan } \\
\text { samping }\end{array}$} & \multicolumn{4}{|c|}{$\begin{array}{l}\text { Faktor penyesuaian untuk hambatan samping dan lebar } \\
\text { bahu } \mathrm{FC}_{\mathrm{SF}}\end{array}$} \\
\hline & & \multicolumn{4}{|c|}{ Lebar bahu efektif $\mathrm{W}_{\mathrm{S}}$} \\
\hline & & $\leq 0,5$ & 1,0 & 1,5 & $\geq 2,0$ \\
\hline \multirow{5}{*}{$4 / 2 \mathrm{D}$} & VL & 0,96 & 0,98 & 1,01 & 1,03 \\
\hline & $\mathrm{L}$ & 0,94 & 0,97 & 1,00 & 1,02 \\
\hline & $\mathrm{M}$ & 0,92 & 0,95 & 0,98 & 1,00 \\
\hline & $\mathrm{H}$ & 0,88 & 0,92 & 0,95 & 0,98 \\
\hline & VH & 0,84 & 0,88 & 0,92 & 0,96 \\
\hline \multirow{5}{*}{$4 / 2 \mathrm{UD}$} & VL & 0,96 & 0,99 & 1,01 & 1,03 \\
\hline & $\mathrm{L}$ & 0,94 & 0,97 & 1,00 & 1,02 \\
\hline & M & 0,92 & 0,95 & 0,98 & 1,00 \\
\hline & $\mathrm{H}$ & 0,87 & 0,91 & 0,94 & 0,98 \\
\hline & VH & 0,80 & 0,86 & 0,90 & 0,95 \\
\hline \multirow{5}{*}{$\begin{array}{c}2 / 2 \text { UD } \\
\text { atau } \\
\text { Jalan satu- } \\
\text { arah }\end{array}$} & VL & 0,94 & 0,96 & 0,99 & 1,01 \\
\hline & $\mathrm{L}$ & 0,92 & 0,94 & 0,97 & 1,00 \\
\hline & M & 0,89 & 0,92 & 0,95 & 0,98 \\
\hline & $\mathrm{H}$ & 0,82 & 0,86 & 0,90 & 0,95 \\
\hline & VH & 0,73 & 0,79 & 0,85 & 0,91 \\
\hline
\end{tabular}

Sumber: MKJI'97

2. Jalan Dengan Kereb

Faktor penyesuaian kapasitas untuk hambatan samping ( $\left.\mathrm{FC}_{\mathrm{SF}}\right)$ ditentukan berdasarkan jarak antara kereb dan penghalang pada trotoar $\mathrm{W}_{\mathrm{k}}$ dan kelas hambatan samping (SFC) seperti terlihat pada Tabel 8. 
Tabel 8. Faktor Penyesuaian Kapasitas Pengaruh Hambatan Samping dan Jarak Kereb Penghalang (FCSF) jalan perkotaan dengan Kereb

\begin{tabular}{|c|c|c|c|c|c|}
\hline \multirow{3}{*}{ Tipe jalan } & $\begin{array}{c}\text { Kelas } \\
\text { hambatan } \\
\text { samping }\end{array}$ & \multicolumn{4}{|c|}{$\begin{array}{c}\text { Faktor penyesuaian untuk hambatan samping dan jarak } \\
\text { kereb-penghalang } \text { FC }_{\mathrm{SF}}\end{array}$} \\
\cline { 3 - 6 } & & \multicolumn{4}{|c|}{ Jarak: kereb-penghalang $\mathrm{W}_{\mathrm{K}}$} \\
\cline { 3 - 6 } & $\mathrm{VL}$ & 0,95 & 0,97 & 0,99 & 1,09 \\
& $\mathrm{~L}$ & 0,94 & 0,96 & 0,98 & 1,00 \\
4/2 D & $\mathrm{M}$ & 0,91 & 0,93 & 0,95 & 0,98 \\
& $\mathrm{H}$ & 0,86 & 0,89 & 0,92 & 0,95 \\
& $\mathrm{VH}$ & 0,81 & 0,85 & 0,88 & 0,92 \\
\hline & $\mathrm{VL}$ & 0,95 & 0,97 & 0,99 & 1,01 \\
& $\mathrm{~L}$ & 0,93 & 0,95 & 0,97 & 1,00 \\
4/2 UD & $\mathrm{M}$ & 0,90 & 0,92 & 0,95 & 0,97 \\
& $\mathrm{H}$ & 0,84 & 0,87 & 0,90 & 0,93 \\
& $\mathrm{VH}$ & 0,77 & 0,81 & 0,85 & 0,90 \\
\hline \multirow{3}{*}{ 2/2 UD } & $\mathrm{VL}$ & 0,93 & 0,95 & 0,97 & 0,99 \\
atau & $\mathrm{L}$ & 0,90 & 0,92 & 0,95 & 0,97 \\
Jalan satu- & $\mathrm{M}$ & 0,86 & 0,88 & 0,91 & 0,94 \\
arah & $\mathrm{H}$ & 0,78 & 0,81 & 0,84 & 0,88 \\
& $\mathrm{VH}$ & 0,68 & 0,72 & 0,77 & 0,82 \\
\hline
\end{tabular}

Sumber: MKJI'97

Faktor penyesuaian untuk ukuran kota ditentukan berdasarkan fungsi jumlah penduduk (Juta) seperti terlihat pada Tabel 9.

Tabel 9. Faktor Penyesuaian Kapasitas untuk Ukuran Kota (FCCS) pada Jalan Perkotaan

\begin{tabular}{|c|c|}
\hline Ukuran kota (Juta penduduk) & Faktor penyesuaian untukukuran kota \\
\hline$<0,1$ & 0,86 \\
$0,1-0,5$ & 0,90 \\
$0,5-1,0$ & 0,94 \\
$1,0-3,0$ & 1,00 \\
$>3,0$ & 1,04 \\
\hline
\end{tabular}

Sumber: MKJI'97

\section{HASIL DAN PEMBAHASAN}

\section{Kondisi Geomterik Pada Ruas Jalan}

Berdasarkan hasil survey inventarisasi jalan di wilayah penelitian sebagai mana

Tabel 10 sebagai berikut: 
Tabel 10 Kondisi Geomterik Pada Ruas Jalan

\begin{tabular}{|c|l|c|c|c|c|c|}
\hline \multirow{2}{*}{ No. Nama Ruas Jalan } & \multirow{2}{*}{$\begin{array}{c}\text { Tipe } \\
\text { Nalan }\end{array}$} & \multirow{2}{*}{$\begin{array}{c}\text { Lebar } \\
(\mathbf{m})\end{array}$} & \multicolumn{2}{|c|}{ Kereb/Bahu } & \multirow{2}{*}{ Ket. } \\
\cline { 5 - 6 } & & kiri & kanan & \\
\hline 1 & Jl. Hasan Basri (Kota - ULM) & $4 / 2 \mathrm{D}$ & 7,50 & 2,00 & 2,30 & median \\
\hline 2 & Jl. Hasan Basri (ULM - BPJS) & $4 / 2 \mathrm{D}$ & 7,50 & 2,00 & 2,30 & median \\
\hline 3 & Jl. Hasan Basri (BPJS - Bundaran) & $4 / 2 \mathrm{D}$ & 7,50 & 2,00 & 2,30 & median \\
\hline 4 & Jl. Hasan Basri (Bundaran - Flamboyan) & $4 / 2 \mathrm{D}$ & 7,00 & 2,30 & 2,30 & median \\
\hline 5 & Jl. Hasan Basri (Flamboyan - Kayutangi I) & $4 / 2 \mathrm{D}$ & 7,00 & 2,30 & 2,30 & median \\
\hline 6 & Jl. Hasan Basri (Kayutangi I - Kota) & $4 / 2 \mathrm{D}$ & 7,00 & 2,30 & 2,30 & median \\
\hline 7 & Jl. Cemara Raya & $2 / 1 \mathrm{D}$ & 5,00 & 1,00 & 1,40 & \\
\hline
\end{tabular}

Hasil Survey

\section{Kapasitas Ruas Jalan}

Dapat dihitung besar kapasitas setiap ruas jalan yang ditinjau seperti yang ditampilkan pada Tabel 11.

Tabel 11. Kapasitas Ruas Jalan

\begin{tabular}{|c|l|c|c|c|c|c|c|}
\hline No. & \multicolumn{1}{|c|}{ Nama Ruas Jalan } & Co & FCw & FCsp & FCsf & FCcs & $\begin{array}{c}\text { C } \\
\text { (smp/jam) }\end{array}$ \\
\hline 1 & Jl. Hasan Basri (Kota - ULM) & 4950 & 0,84 & 1 & 0,94 & 0,94 & 3674 \\
\hline 2 & Jl. Hasan Basri (ULM - BPJS) & 4950 & 0,84 & 1 & 0,94 & 0,94 & 3674 \\
\hline 3 & Jl. Hasan Basri (BPJS - Bundaran) & 4950 & 0,84 & 1 & 0,94 & 0,94 & 3674 \\
\hline 4 & Jl. Hasan Basri (Bundaran - Flamboyan) & 3300 & 1,00 & 1 & 0,97 & 0,94 & 3009 \\
\hline 5 & Jl. Hasan Basri (Flamboyan - Kayutangi I) & 3300 & 1,00 & 1 & 0,97 & 0,94 & 3009 \\
\hline 6 & Jl. Hasan Basri (Kayutangi I - Kota) & 3300 & 1,00 & 1 & 0,97 & 0,94 & 3009 \\
\hline 7 & Jl. Cemara Raya & 3300 & 0,84 & 1 & 0,86 & 0,94 & 2241 \\
\hline
\end{tabular}

\section{Hasil Analisis}

\section{Kinerja Jaringan Jalan}

Kinerja jalan dapat dilihat dari V/C rationya. Nilai V/C merupakan salah satu Indikator TingkatPelayanan (ITP) yang berfungsi sebagai evaluasi terhadap tingkat kinerja lalu lintas. Nilai ITPditetapkan berdasarkan nilai kuantitatif V/C, kecepatan perjalanan, dan faktor lain yang ditentukan berdasarkan nilai kualitatif seperti kebebasan pengemudi dalam memilih kecepatan,dan nilai dari tundaan kendaraan (delay).

\section{Kondisi Eksisting}

Kinerja jaringan jalan pada kondisi eksisting dengan mempertimbangkan sistem jaringan yangberlaku kepada setiap ruas jalan. Analisa nilai indikator tingkat pelayanan (ITP) setiap ruas direkapitulasi seperti yang dijabarkan pada Tabel 12.

Tabel 12. Nilai ITP Ruas yang Ditinjau pada Jam Puncak Kondisi Eksisting

\begin{tabular}{|l|c|c|}
\hline \multicolumn{1}{|c|}{ Ruas } & DS & ITP \\
\hline Jl. Hasan Basri (Kota - ULM) & 0,64 & C \\
\hline Jl. Hasan Basri (ULM - BPJS) & $\mathbf{0 , 7 9}$ & D \\
\hline Jl. Hasan Basri (BPJS - Bundaran) & $\mathbf{0 , 8 0}$ & D \\
\hline Jl. Hasan Basri (Bundaran - Flamboyan) & 0,68 & C \\
\hline Jl. Hasan Basri (Flamboyan - Kayutangi I) & 0,67 & C \\
\hline Jl. Hasan Basri (Kayutangi I - Kota) & 0,68 & C \\
\hline Jl. Cemara Raya & 0,30 & A \\
\hline
\end{tabular}

Hasil Analisis 
Dari Tabel 12. terlihat bahwa dengan mengacu kepada Peraturan Menhub. No. PM 96 Tahun 2015 tentang Manajemen dan Rekayasa Lalu-lintas, dapat disimpulkan secara umum ruas-ruas jalan yang ditinjau mempunyai tingkat kinerja yang cukup dan sudah memenuhi persyaratan yang ditentukan. ITP = D merupakan nilai ITP terendah terjadi pada segmen ruas Jalan Hasan Basri (BPJS - Bundaran) yang juga memiliki nilai V/C ratio terbesar yaitu 0,80 . Hal ini memperlihatkan bahwa pada arus stabil dengan volume lalu lintas sedang dan kecepatan sekurang-sekurangnya 50 (lima puluh) kilometer per jam, kepadatan lalu lintas sedang namun fluktuasi volume lalu lintas danhambatan temporer dapat menyebabkan penurunan kecepatan yang besar, dan pengemudi memiliki kebebasan yang sangat terbatas dalam menjalankan kendaraan, kenyamanan rendah, tetapi kondisi ini masih dapat ditolerir untuk waktu yang singkat.

\section{Kondisi Saat Pembangunan}

Kinerja jaringan jalan saat Pembangunan Fakultas Kedokteran Gigi disimulasikan untuk melihat perubahan yang terjadi khususnya tingkat pelayanan ruas-ruas jalan yang pada kawasan yang ditinjau akibat aktifitas lalu lintas kendaraan. Pada analisis ini pergerakan kendaraan menuju daerah rencana berdasarkan Tabel 13.

Tabel 13. Nilai ITP Ruas yang Ditinjau pada Jam Puncak Kondisi Saat Pembangunan

\begin{tabular}{|l|c|c|}
\hline \multicolumn{1}{|c|}{ Ruas } & DS & ITP \\
\hline Jl. Hasan Basri (Kota - ULM) & 0,65 & C \\
\hline Jl. Hasan Basri (ULM - BPJS) & 0,79 & D \\
\hline Jl. Hasan Basri (BPJS - Bundaran) & 0,80 & D \\
\hline Jl. Hasan Basri (Bundaran - Flamboyan) & 0,68 & C \\
\hline Jl. Hasan Basri (Flamboyan - Kayutangi I) & 0,68 & C \\
\hline Jl. Hasan Basri (Kayutangi I - Kota) & 0,68 & C \\
\hline Jl. Cemara Raya & 0,30 & A \\
\hline
\end{tabular}

\section{Hasil Analisis}

Dari Tabel 13. terlihat bahwa tidak terjadi perubahan pada ITP akibat pergerakan yangditimbulkan oleh pembangunan Fakultas Kedokteran Gigi Berdasarkan nilai V/C dan ITP semua ruas tidak terjadi perubahan seperti kondisi eksisting.

\section{Kondisi Pasca Pembangunan}

Kinerja jaringan jalan pasca Pembangunan Fakultas Kedokteran Gigi disimulasikan setelah akses sudah difungsikan yaitu 1 tahun sejak pembangunan. Peningkatan beban lalu lintas pada jaringan jalan lebih dikarenakan oleh pertumbuhan arus lalu lintas itu sendiri yaitu sebesar peningkatan laju pertumbuhan lalu lintas seperti dijabarkan pada Tabel 14. 
Tabel 14. Nilai ITP Ruas yang Ditinjau pada

Jam Puncak Kondisi Pasca Pembangunan

\begin{tabular}{|l|c|c|}
\hline \multicolumn{1}{|c|}{ Ruas } & DS & ITP \\
\hline Jl. Hasan Basri (Kota - ULM) & 0,66 & C \\
\hline Jl. Hasan Basri (ULM - BPJS) & $\mathbf{0 , 8 1}$ & D \\
\hline Jl. Hasan Basri (BPJS - Bundaran) & $\mathbf{0 , 8 2}$ & D \\
\hline Jl. Hasan Basri (Bundaran - Flamboyan) & 0,69 & C \\
\hline Jl. Hasan Basri (Flamboyan - Kayutangi I) & 0,69 & C \\
\hline Jl. Hasan Basri (Kayutangi I - Kota) & 0,69 & C \\
\hline Jl. Cemara Raya & 0,30 & B \\
\hline
\end{tabular}

Hasil Analisis

Ditinjau dari nilai V/C ratio yang terjadi pada ruas-ruas jalan pasca pembangunan seperti Tabel 14, perubahan yang terjadi masih kecil berkisar \pm 0,01 . Berdasarkan nilai ITP semua ruas tidak terjadi perubahan seperti kondisi pembangunan.

Penurunan nilai V/C ratio terbesar terjadi pada ruas Jalan Hasan Basri (BPJSBundaran) dari 0,80 menjadi 0,82 dan kenaikan pada ruas Jalan Hasan Basri $($ ULM - BPJS) dari 0,79 menjadi 0,81 ITP = D. Hal ini karena aktifitas pergerakan dari/ke Fakultas Kedokteran Gigi, serta pertumbuhan lalu lintas secara umum.

\section{Kondisi 5 (Lima) Tahun Mendatang}

Proyeksi kinerja jaringan jalan pada 5 (lima) tahun yang akan datang akibat Pembangunan Fakultas Kedokteran Gigi disimulasikan Tabel 15 sebagai berikut:

Tabel 15. Nilai ITP Ruas yang Ditinjau pada

Jam Puncak Kondisi 5 (Lima) Tahun Mendatang

\begin{tabular}{|l|c|c|}
\hline \multicolumn{1}{|c|}{ Ruas } & DS & ITP \\
\hline Jl. Hasan Basri (Kota - ULM) & 0,71 & C \\
\hline Jl. Hasan Basri (ULM - BPJS) & $\mathbf{0 , 8 6}$ & D \\
\hline Jl. Hasan Basri (BPJS - Bundaran) & $\mathbf{0 , 8 7}$ & D \\
\hline Jl. Hasan Basri (Bundaran - Flamboyan) & 0,73 & C \\
\hline Jl. Hasan Basri (Flamboyan - Kayutangi I) & 0,72 & C \\
\hline Jl. Hasan Basri (Kayutangi I - Kota) & 0,73 & C \\
\hline Jl. Cemara Raya & 0,34 & B \\
\hline
\end{tabular}

Hasil Analisis

Ditinjau dari nilai V/C ratio yang terjadi pada ruas-ruas jalan pada 5 (lima) tahun mendatang dibandingkan tahun pertama selesainya pembangunan Fakultas Kedokteran Gigi, didapat kenaikan nilai V/C ratio yang terjadi berkisar antara 0,07 lebih buruk dari Pasca Pembangunan. Ditinjau dari nilai ITP, penurunan terjadi pada ruas J1. Hasan Basri (BPJS - Bundaran) dan didapat nilai ITP D.

\section{Kondisi 5 (Lima) Tahun Mendatang dengan Penanganan}

Penanganan manajemen lalu lintas perlu dilakukan untuk memperbaiki kinerja jaringan pada kawasan ULM terutama pada ruas Jalan Hasan Basri (ULM Uturn BPJS) yang mempunyai ITP D. Kontribusi pergerakan bangkitan dari 
ULM yang cukup besar yaitu $32 \%$ pembebanan lalu lintas menjadi salah satu yang perlu dipertimbangkan. Pergerakan bangkitan dari ULM yang diarahkan belok kiri memperlihatkan kondisi yang tidak normal. Pergerakan belok kiri yang normal menurut MKJI 1997 adalah sebesar 15\%.

Pergerakan bangkitan (keluar dari ULM) berdasarkan data memperlihatkan 68\% arus lalu lintasmelakukan putar balik menuju Zona Kota, Zona Kayutangi I, dan Zona Cendana. Oleh karena itu perlu penanganan dengan menjadikan akses keluar ULM menjadi simpang tiga dengan membuka median yang ada. Simulasi kinerja jaringan jalan pada 5 (lima) tahun yang akan datang dengan penanganan dampak lalu lintas Tabel 16. sebagai berikut:

Tabel 16. Nilai ITP Ruas yang Ditinjau pada

Jam Puncak Kondisi 5 (Lima) TahunMendatang dengan Penanganan

\begin{tabular}{|l|c|c|}
\hline \multicolumn{1}{|c|}{ Ruas } & DS & ITP \\
\hline Jl. Hasan Basri (Kota - ULM) & 0,71 & C \\
\hline Jl. Hasan Basri (ULM - BPJS) & $\mathbf{0 , 7 1}$ & $\mathbf{C}$ \\
\hline Jl. Hasan Basri (BPJS - Bundaran) & $\mathbf{0 , 7 2}$ & $\mathbf{C}$ \\
\hline Jl. Hasan Basri (Bundaran - Flamboyan) & 0,54 & $\mathrm{C}$ \\
\hline Jl. Hasan Basri (Flamboyan - Kayutangi I) & 0,72 & $\mathrm{C}$ \\
\hline Jl. Hasan Basri (Kayutangi I - Kota) & 0,73 & $\mathrm{C}$ \\
\hline Jl. Cemara Raya & 0,34 & $\mathrm{~B}$ \\
\hline
\end{tabular}

Hasil Analisis

Ditinjau dari nilai V/C ratio dengan dilakukan penanganan manajemen simpang tiga, berdasarkan Tabel 16. terlihat ada perbaikan kinerja pada ruas Jalan Hasan Basri (ULM - BPJS) dari 0,86 menjadi 0,71 dan Jalan Hasan Basri (BPJS - Bundaran) dari 0,87 menjadi 0,73.Ditinjau dari nilai ITP, penanganan dengan menerapkan manajemen simpang tiga memperbaikinilai ITP kedua ruas tersebut menjadi ITP C.

\section{Kinerja Simpang}

Peninjauan terhadap kinerja simpang perlu dilakukan akibat aktifitas lalu lintas yang akan ditimbulkan oleh kegiatan sebelum dan sesudah pembangunan, serta dimulai dioperasikannya kegiatan Fakultas Ked. Gigi tersebut. Dari hasil simulasi pembebanan jaringan jalan, mempunyai indikasi dampak terhadap ruas Jl. Hasan Basri sebagai akses keluar/masuk lingkungan ULM. Akses keluar/masuk Fakultas Ked. Gigi tidak mempengaruhi secara langsung terhadap kinerja simpang tersebut karena diluar kawasan simpang $(>77 \mathrm{~m})$. Kinerja simpang perlu ditinjau sehubungan dengan penambahan bangkitan dan tarikan dari/ke gedung rencana tersebut. Simpang untuk semua kondisi ditampilkan dalam Tabel 17. 
Tabel 17. Hasil Analisis Simpang Tak Bersinyal

\begin{tabular}{|c|c|c|c|c|c|c|c|}
\hline \multirow{3}{*}{ No. } & \multirow{3}{*}{ Kondisi Simpang } & \multicolumn{6}{|c|}{ Simpang ULM - Jl. Hasan Basri } \\
\hline & & \multirow{2}{*}{$\begin{array}{l}\text { Rasio arus } \\
\text { jalan minor } \\
\quad \text { (Pmi) }\end{array}$} & \multirow{2}{*}{ DS } & \multicolumn{2}{|c|}{$\begin{array}{l}\text { Tundaan Rata-rata } \\
\text { (det/smp) }\end{array}$} & \multirow{2}{*}{$\begin{array}{c}\text { Peluang } \\
\text { Antrian } \\
\text { Rata-rata } \\
(\%)\end{array}$} & \multirow{2}{*}{ ITP } \\
\hline & & & & $\begin{array}{l}\text { Lalu } \\
\text { Lintas }\end{array}$ & Simpang & & \\
\hline 1 & Eksisting & 0,405 & 1,03 & 16,48 & 20,48 & 64 & $\mathrm{C}$ \\
\hline 2 & Pra-pembangunan & 0,406 & 1,031 & 16,56 & 20,56 & 64 & $\mathrm{C}$ \\
\hline 3 & Pasca-pembangunan & 0,404 & 1,05 & 17,65 & 21,65 & 66 & $\mathrm{C}$ \\
\hline 4 & 5 th Pasca- pembangunan & 0,381 & 1,136 & 25,09 & 29,09 & 78,5 & $\mathrm{D}$ \\
\hline
\end{tabular}

Hasil Analisis

Data estimasi perubahan arus lalu lintas akibat pembukaan median untuk belok kanan dari ULM menjadikan simpang bersinyal maka hasil analisis sebagaimana Tabel 18.

Tabel 18. Hasil Analisis Simpang Bersinyal

\begin{tabular}{|c|l|c|c|c|c|c|c|}
\hline & \multicolumn{1}{|c|}{ Kondisi Simpang } & Fase & DS & $\begin{array}{l}\text { Waktu } \\
\text { Hijau } \\
\text { No. }\end{array}$ & $\begin{array}{l}\text { Cyct) } \\
\text { time } \\
\text { (det) }\end{array}$ & $\begin{array}{l}\text { Tundaan } \\
\text { Rata-rata } \\
\text { Simpang } \\
\text { (det/smp) }\end{array}$ & ITP \\
\hline 5 & $\begin{array}{l}5 \text { th Pasca- } \\
\text { pembangunandengan } \\
\text { penanganan }\end{array}$ & 1 & 0,845 & 32 & 66 & 22,02 & $\mathrm{C}$ \\
\cline { 3 - 9 }
\end{tabular}

Hasil Analisis

\section{PENUTUP}

\section{Kesimpulan}

Berdasarkan hasil dari penelitian dan analisis data yang dilakukan, maka disarankan hal-hal sebagai berikut:

1. Semua ruas jalan yang ditinjau mengalami penurunan nilai DS sebagai dampak adanya Fakultas Kedokteran Gigi disertai pertumbuhan lalu lintas yang ada. Nilai penurunan DS terbesar dialami segmen ruas J1. Hasan Basri (BPJS Bundaran) sebesar 0,07. Penurunan DS terkecil terjadi pada segmen ruas Jl. Cemara Raya sebesar 0,04.

2. Berdasarkan "Pedoman analisis dampak lalu Lintas jalan akibat pengembangan kawasan diperkotaan", Kriteria dampak lalu lintas pada ruas jalan yang membutuhkan penanganan adalah apabila DS ruas jalan tersebut kejenuhan lebih dari atau sama dengan 0,7

3. Kondisi eksisting J1. Hasan Basri (BPJS - Bundaran) sudah memperlihatkan nilai DS dibawah nilai batas (> 0,75). Kondisi ini tanpa maupun dengan adanya pembangunan sudah perlu ada penanganan. Dengan dilakukan penanganan manajemen lalu lintas dengan melakukan manajemen simpang bersinyal nilai DS menjadi kurang dari 0,75. Oleh karena itu dengan penanganan tersebut, dapat dijelaskan bahwa dampak lalu lintas dari gedung rencana baik pada saat pembangunan dan pasca pembangunan berdampak negatif.

4. Ditinjau dari kinerja simpang yaitu simpang Jl. Hasan Basri (Kota - ULM), Berdasarkan "Pedoman analisis dampak lalu Lintas jalan akibat pengembangan kawasan diperkotaan"kedua simpang tersebut tidak termasuk dalam kategori 
dampak lalu lintas jalan yang membutuhkan penanganan khusus karena tundaan yang terjadi $<30 \mathrm{dt} / \mathrm{smp}$.

\section{Saran}

Berdasarkan kesimpulan yang diperoleh dari hasil penelitian, maka dapat diberikan beberapa saran sebagai berikut :

1. Hasil analisis dampak lalu lintas yang terjadi diatas dilakukan pada kondisi lalu lintas bergerak pada kondisi normal. Oleh karena itu, untuk mempertahankan kondisi tersebut maka perlu tindakan pencegahan agar tidak terjadi gangguan kelancaran, keselamatan, dan kenyamanan pengguna jalan

2. Perlunya koordinasi dengan pihak terkait koordinasi keamanan, keselamatan ketertiban kelancaran lalu lintas jalan.

3. Perlunya pengawasan dan evaluasi unjuk kerja lalu lintas sekitar lokasi universitas lambung mangkurat (ULM) secara periodik.

4. Dampak lalu lintas ini dilakukan untuk tahun selanjutnya perlu melakukan review dan evaluasi terhadap kinerja jaringan jalan agar tetap baik.

5. Perlu penerapan usulan-usulan dampak lalu lintas yang telah dikaji, sehingga dampak yang ditimbulkan terhadap lalu lintas dapat diminimalisir.

\section{DAFTAR PUSTAKA}

Undang-Undang Republik Indonesia Nomor 38 Tahun 2004 tentang Jalan

Undang-Undang (UU) Nomor 22 Tahun 2009 tentang Lalu Lintas dan Angkutan Jalan.

Peraturan Pemerintah (PP) Nomor 32 Tahun 2011 tentang Manajemen dan Rekayasa, Analisis Dampak, serta Manajemen Kebutuhan Lalu Lintas. Pemerintah Republik Indonesia. 2009.

Peraturan Menteri Perhubungan Nomor: PM 17 Tahun 2021 tentang Penyelenggaraan Analisis Dampak Lalu Lintas.

Peraturan Daerah Kota Banjarmasin Nomor 13 Tahun 2014 tentang Penyelenggaraan Analisis Dampak Lalu Lintas di Jalan.

Direktorat Jenderal Bina Marga Direktorat Bina Jalan Kota, Manual Kapasitas Jalan Indonesia (MKJI) 1997

Hobbs, F.D, Taffic Planning And Engineering, 2nd Edition, Oxford Pergamon Press, 1979.

Morlok, E. K, (1991), Pengantar Teknik dan Perencanaan Transportasi, Erlangga, Jakarta.

Kelsen, Hans, General Theory of Law end State Transleted by: Andres Wedberg, New York, Rusell Rusell, 1961.

Ofyar Z., Tamin, Perencanaan dan Pemodelan Transportasi, Edisi 1 Penerbit ITB, Bandung, 1997.

, Perencanaan dan Pemodelan Transportasi, Edisi 2 Penerbit ITB, Bandung, 2000.

Pujatmoko, Sri, Perizinan Problem dan Upaya Pembenahan, Gramedia, Jakarta, 2009.

S., Warpani, Merencanakan Sistem Perangkutan, Penerbit ITB, Bandung, 1990. 